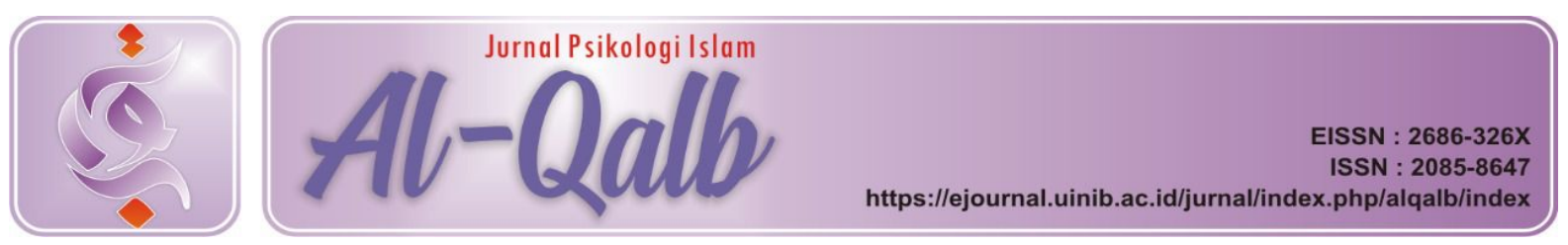

\title{
HUBUNGAN ESQ DENGAN MOTIVASI BERPRESTASI PADA MAHASISWA
}

Received: $23^{\text {th }}$ December 2014; Revised: 07th January 2015; Accepted: $23^{\text {th }}$ February 2015

\section{Murisal}

IAIN Imam Bonjol Padang

Email: muri_dewi@yahoo.com

\begin{abstract}
Abstrak: Penelitian ini merupakan penelitian dan pengembangan yang bertujuan untuk melihat hubungan antara ESQ dengan motivasi berprestasi pada mahasiswa semester 3 Fakultas Ushuluddin IAIN Imam Bonjol Padang. Lebih lanjut tujuan penelitian ini ialah untum memperoleh,(1) gambaran tentang ESQ mahasiswa semester 3 Fakultas Ushuludin IAIN Imam Bonjol Padang, (2) gambaran motivasi berprestasi mahasiswa semester 3 Fakultas Ushuluddin IAIN Imam Bonjol Padang, (3) gambaran hubungan ESQ dengan motivasi berprestasi mahasiswa semester 3 Fakultas Ushuluddin IAIN Imam Bonjol Padang. Penelitian ini ditujukan pada seluruh mahasiswa Fakulltas Ushuluddin IAIN Imam Bonjol Padang angkatan 2013/2014 yang berjumlah 162 orang dan sampelnya sebanyak 101 orang. Penelitian ini menggunakan skala ESQ dan skala motivasi. Metode uji normalitas yang akan digunakan adalah metode CorrectedItem-TotalCorrelation. Pengujian ini menggunakan program SPSS 16,0for windows dengan menggunakan test for linearity pada taraf signifikansi 0,05 . Berdasarkan hasil uji hipotesis melalui analisis regresi linier sederhana menunjukkan bahwa nilai pearson correlation antara variabel nilai dasar ESQ dengan motivasi berprestasi sebesar 0,174 dan nilai signifikansi 0,082 (nilai $\mathrm{p}>0,05$ ) yang berarti pada taraf signifikansi antara dua variabel menunjukkan adanya dua variabel tidak menunjukkan adanya hubungan antara nilai dasar ESQ dan Motivasi berprestasi $\left(\mathrm{H}_{0}\right.$ diterima $\mathrm{H}_{a}$ ditolak). Maka kesimpulannya adalah tidak ada hubungan antara Nilai dasar ESQ dengan Motivasi Berprestasi.
\end{abstract}

Kata Kunci: ESQ, Motivasi Berprestasi

$\mathrm{M}$ enurut Mc Clelland (dalam Djaali, 2008)mengemuka-kan bahwa motivasi berprestasi adalah kondisi fisiologis dan psikologis yang terdapat di dalam diri siswa yang mendorongnya untuk melakukan aktivitas tertentu dan berprestasi setinggi mungkin. Kondisi fisiologis ialah mencakup jasmani seseorang, seperti tinggi, pendek, serta penampilan fisik yang normal dan tidak lain dari fisik orang normal, sedangkan kondisi psiko-logis mencakup bagian emosi, aspirasi, tingkah laku, kreativitas pada diri seseorang serta kebutuhan untuk berprestasi. Kondisi-kondisi fisiologis dan kondisi psikologis tersebut merupakan suatu bagian konsep diri yang ada dalam diri seseorang. Fernald \& Fernald (Robbins, 
1996) menambahkan bahwa tumbuh kembangnya motivasi berprestasi dipengaruhi oleh keluar-ga, kebudayaan, tingkah laku, jenis kelamin, konsep diri, pengalaman-pengalaman pada tahun-tahun kehi-dupan, latar belakang budaya, lingkungan tempat proses perkulia-han berlangsung dan lain- lain. Daribeberapa pendapat yang dikemuka-kan oleh parah ahli dia atas bahwa seseorang akan termotivasi atau terdorong untuk melakukan apa yang diinginkannya seperti dalam belajar, atau kekuatan untuk meningkatkan spritual dalam belajar.

Atkitson (Djaali, 2008) mengemukakan bahwa seseorang yang mempunyai motivasi berpres-tasi tinggi pada umumnya harapan akan kesuksesan selalu mengalahkan rasa takut akan mengalami kegagalan dan selalu merasa optimis dalam mengerjakan setiap apa yang dihadapinya, sehingga setiap saat selalu termotivasi untuk mencapai tujuan. Rasa takut akan mengalami kegagalan dalam diri seseorang tertanam dalam konsep diri yang negatif yang menganggap bahwa diri sendiri tidak mempunyai kemam-puan untuk berkompetisi. Sedang-kan, Sanjaya (2006) mengatakan tujuan berkompetisi adalah mengembangkanPengetahuan, Pemahaman, Kecakapan, Nilai Sikap, dan Minat mahasiswa agar dapat melakukan sesuatu dalam bentuk kemahiran disertai tanggung jawab.

Hal senada juga dikemukakan oleh seorang tokoh yang melakukan pelatihan terhadap pelajar maupun tenaga kerja yang ada di Indonesia dengan menggunakan beberapa penerapan dalam ESQ, Emosional Spiritual Quotian (selanjutnya ditulis ESQ). Sehingga seseorang tersebut lebih termotivasi dalam melakukan pekerjaannya.

Dalam ESQ kecerdasan spiritual adalah kemampuan untuk memberi makna spiritual terhadap pemikiran, perilaku dan kegiatan, serta mampu menyinergikanIntelegensi Quotian(IQ),
Emosional Quotian(EQ), Spiritual Quotian(SQ). secara komprehensif (Ary Ginanjar,2010:13).

Dari ketiga kecerdasan di atas yaitu: IQ , EQ, dan SQ.Kecerdasan pertama, adalah IQ merupakan kecerdasan yang dibawa sejak lahir dan dipengaruh oleh didikan dan pengalaman.IQ adalah kemampuan yang diperlukan untuk menjalankan kegiatan mental.Unsur-unsur yang terdapat dalam IQ adalah kecerdasan numerous, pemahaman, penalaran induktif, penalaran deduktif, visua-lisasi ruang ingatan.

William Stern dalam (Purwanto,2010:52) mengemukakan: Intelegensi ialah kesanggupan untuk menyesuaikan diri kepada kebutuhan baru, dengan menggu-nakan alat-alat berpikir yang sesuai dengan tujuannya. Dan William Stern berpendapat bahwa intelegensi sebagian besar tergantung dengan dasar dan turunan.

Kecerdasan kedua, EQ merupakan kemampuan merasakan, memahami, dan secara efektif menalarkan daya serta kepekaan emosi sebagai sumber energi, informasi, koneksi, dan pengaruh yang manusiawi. Menurut James (dalamSobur, 2003:399) emosi adalah "kecenderungan untuk memi-liki perasaan yang khas bila berhadapan dengan objek tertentu dalam lingkungan".

Kecerdasan ketiga,SQ Zohar dan Marshall mengikutsertakan konteks nilai sebagai suatu bagian dari proses berpikir atau berkecer-dasan dalam hidup yang bermakna, untuk ini mereka mempergunakan "kecerdasan spiritual" atau SQ (Ary Ginanjar, 2010:13).

Melalui metode ESQ, ketiga kecerdasan di atas dapat dibangun dengan memadukan kecerdasan Intelligent, Emosional dan spiritual yang dikembangkan oleh Ary Ginanjar Agustian, dengan menggunakan teknologi multimedia. 
Salah satu bentuk kegiatan atau pelatihan yang digunakan untuk membangun tiga kecerdasan tersebut adalah pengucapan Nilai dasar ESQ yang dikembangkan oleh Ari Ginanjar Agustian. Nilai dasar ESQ tersebut diambil dari nama atau sifat Allah yang berjumlah 99 dalam Al-qur'an yang disebut "Asma'ulhusna". Untuk lebih menyederhana-kannya, inilah spiritual core values yang diambil dari "asmaul husna" antara lain: jujur, tanggung jawab, visioner, disiplin, kerjasama, adil dan peduli.

Dalam dunia pendidikan ESQ juga digunakan untuk berbagai kepentingan dalam membangun kualitas dan karakter mahasiswa melalui pelatihan-pelatihan ESQ tersebut. Dengan adanya pelatihan ESQ maka diharapkan dapat membantu proses pendidikan yang berkualitas dan dapat membangun kemampuan motivasi berprestasi yang lebih baik. Namun di beberapa tempat dan kasus ditemukan tidak seperti yang diharapkan.

\section{PEMBAHASAN}

\section{GambaranBentuk Nilai Dasar ESQ}

Gambaran bentuk nilai dasar ESQ mahasiswa Fakultas Ushuluddin semester tiga IAIN Imam Bonjol Padang, diukur dengan menggunakan skala Nilai dasar ESQ sebanyak 20 item dengan jumlah subjek 101 orang.

Tabel.1

\section{Gambaran Tingkat /Bentuknilaidasar ESQ}

\begin{tabular}{cccc}
\hline No. & Kategori & Frekuensi & Persentase \\
\hline 1. & Tinggi $(>61)$ & 8 & $8 \%$ \\
2 & Sedang $(51-61)$ & 52 & $51 \%$ \\
3 & Rendah $(<50)$ & 41 & $41 \%$ \\
\hline
\end{tabular}

Sumber Data Penelitian

Berdasarkan tabel di atas, bahwa dari 101 subjek yang diteliti, sebanyak 8 orang atau $8 \%$ memiliki tingkat atau bentukNilai dasar ESQ tinggi (positif). Sebanyak 52 orang atau $51 \%$ memiliki tingkat atau bentuknilai dasar ESQ yang sedang. Sebanyak 41 orang atau $41 \%$ rendah. Dari besarnya persentase nilai dasar ESQ pada tabel tersebut, menunjukkan bahwa mahasiswa Fakultas Ushuluddin IAIN
Imam Bonjol Padang Padang lebih dominan memiliki tingkat Nilai dasar ESQyang sedang.

\section{Gambaran Motivasi Berprestasi}

Tingkat Motivasi berprestasi pada mahasiswa Fakultas Ushulud-din IAIN Imam Bonjol Padangdiukur dengan menggunakan skala Motivasi berprestasi sebanyak 42 item dengan jumlah subjek 101 orang

\section{Tabel.2}

Gambaran Tingkat Motivasi Berprestasi

\begin{tabular}{cccc}
\hline No. & Kategori & Frekuensi & Persentase \\
\hline 1. & Tinggi $(>127)$ & 23 & $23 \%$ \\
& Sedang $(117-127)$ & 23 & $23 \%$ \\
2. & Rendah $(<116)$ & 55 & $54 \%$ \\
\hline
\end{tabular}


Berdasarkan tabel diatas, bahwa dari 101 subjek yang diteliti, sebanyak 23 orang atau $23 \%$ memi-liki tingkat Motivasi Berprestasi yang tinggi. Sebanyak 23 orang atau $23 \%$ memiliki tingkat motivasi berprestasi sedang.Sebanyak 55 orang atau $54 \%$ memiliki tingkat motivasi berprestasi rendah. Dari besarnya persentase Motivasi Berprestasi pada tabel tersebut, menunjukkan bahwa Mahasiswa fakultas Ushuluddin IAIN Imam Bonjol Padang lebih dominan memiliki tingkat Motivasi berprestasi yang rendah.

\section{Uji Normalitas Data}

Uji normalitas dilakukan untuk mengetahui apakah populasi data berdistribusi normal atau tidak.Uji ini dilakukan karena data berupa data internal. Dalam uji ini akan dilakukan uji liliefors yaitu dengan melihat nilai pada kolmogorov semirnov. Data dinyatakan berdistri-busi normal jika signifikansi lebih besar dari 0,05 $(>0,05)$. Pengolahan data dilakukan dengan menggunakan program SPSS 16,0for windows. Hasil uji normalitas sebaran skor nilai dasar ESQ dan motivasi berprestasi adalah sebagai berikut:

Tabel.3

Tests of Normality

\begin{tabular}{lcccccc}
\hline & \multicolumn{3}{c}{ Kolmogorov-Smirnov $^{\mathrm{a}}$} & \multicolumn{3}{c}{ Shapiro-Wilk } \\
\hline & Statistic & Df & Sig. & Statistic & Df & Sig. \\
\hline ESQ & .134 & 101 & .000 & .929 & 101 & .000 \\
$\begin{array}{l}\text { Motivsiberpre } \\
\text { stasi }\end{array}$ & .107 & 101 & .006 & .968 & 101 & .015 \\
\hline
\end{tabular}

a. Lilliefors Significance Correction

Dari hasil tabel di atas dapat dilihat bahwa $E S Q$ (x) memiliki P-value $=0,000$ untuk Uji Normalitas Lilliefors (Kolmogorov-Smirnov)dan $P$-value $=$ 0,000 untuk Uji Normalitas Shapiro-Wilk. KarenaKedua $P$-value lebih kecil dari $\alpha=$ 0,05, maka :

Ho: Data berasal dari populasi yang tidak berdistribusi normal.

Demikian pula untuk skor Motivasi Berprestasi memiliki $P$-value $=$ 0,006 untuk Uji Normalitas Lilliefors (Kolmogorov-Smirnov) dan P-value = 0,015untuk Uji Normalitas Shapiro-Wilk. Kedua $P$-value lebih kecil dari $\alpha=0,05$, sehingga $H o$ : data berasal dari populasi yang tidak terdistribusi normal.

Kesimpulan dari hasil uji normalitas ini adalah bahwa data
skorESQ dan motivasi berprestasiberdasar dari populasi yang tidak terdistribusi normal.

\section{Uji Linearitas}

Uji linearitas bertujuan untuk mengetahui apakah 2 variabel mempunyai hubungan yang linear atau tidak secara signifikan.Hal ini bertujuan sebagai syarat dalam analisis korelasi. Pengujian ini menggunakan program SPSS 16,0 for windows dengan menggunakan test for linearity pada taraf signifikansi 0,05 kedua variabel dinyatakan mempunyai hubungan linear jika signifikancy linearity kurang dari 0,05 . Hasil pengujian linearitas skala nilai dasar ESQ dan skala Motivasi berprestasi adalah sebagai berikut. 
dasar ESQ dan skala Motivasi berprestasi adalah sebagai berikut.

Tabel.4

ANOVA Table

\begin{tabular}{|c|c|c|c|c|c|c|c|}
\hline & & & $\begin{array}{l}\text { Sum of } \\
\text { Squares }\end{array}$ & Df & $\begin{array}{l}\text { Mean } \\
\text { Square }\end{array}$ & $\mathrm{F}$ & Sig. \\
\hline \multirow{5}{*}{$\begin{array}{l}\text { Motivsiberpre } \\
\text { tasi * ESQ }\end{array}$} & \multirow{3}{*}{$\begin{array}{l}\text { Between } \\
\text { Groups }\end{array}$} & (Combined) & 10447.725 & 26 & 401.836 & .711 & .834 \\
\hline & & Linearity & 1577.814 & 1 & 1577.814 & 2.791 & .099 \\
\hline & & $\begin{array}{l}\text { Deviation from } \\
\text { Linearity }\end{array}$ & 8869.910 & 25 & 354.796 & .628 & .904 \\
\hline & \multicolumn{2}{|c|}{ Within Groups } & 41828.948 & 74 & 565.256 & & \\
\hline & \multicolumn{2}{|l|}{ Total } & 52276.673 & 100 & & & \\
\hline
\end{tabular}

Dari data tabel diatas, dapat diketahui bahwa nilai signifikansi pada linearitas sebesar 0,99. Karena signifikansi lebih besar dari $0,05(0,99>0,05)$ maka dapat disimpulkan bahwa antara variabelnilai dasar ESQdan Motivasi berprestasi tidak terdapat hubungan yang linier. Dengan ini maka asumsi linieritas tidak terpenuhi.

\section{Uji Homogenitas}

Uji homogenitas digunakan sebagai uji prasyarat jika akan melakukan uji $\mathrm{T}$ sampel bebas (Indenpenden Sampel T Test) dan uji varian satu saja (One Way Anova). Uji ini untuk mengetahui apakah beberapa varian populasi data adalah sama atau tidak. Jika signifykansi lebih dari 0,05 maka dapat dikatakan bahwa varian dari dua atau lebih kelompok data adalah samadan jika nilai signifikansi kurang dari 0,05 maka varian dari dua atau lebih kelompok tidak sama atau tidak homogen, berikutini table ujihomogenitas.

Tabel.5

Test of Homogeneity of Variances

\begin{tabular}{lllll}
\hline $\begin{array}{l}\text { Levene } \\
\text { Statistic }\end{array}$ & df1 & df 2 & Sig. \\
\hline
\end{tabular}

Test of Homogeneity of Variances

\begin{tabular}{rrrrr}
\hline $\begin{array}{l}\text { Levene } \\
\text { Statistic }\end{array}$ & df1 & df2 & Sig. \\
\hline 2.073 & 14 & 74 & .023 \\
\hline
\end{tabular}

Berdasarkan Tabel.5 diatas dapat diketahui bahwa nilai signifikan 0,023 karena signifikan lebih kecil dari 0,05 maka dapat disimpulkan bahwa kedua kelompok data nilai dasar ESQdan Motivasi berprestasi mempunyai varian tidak sama atau variasi nilai yang tidak sama sehingga disebut juga tidak homogen.

\section{Uji Hipotesis}

Uji hipotesis untuk penelitian ini dilakukan untuk mengetahui hubungan antaranilai dasar ESQdan motivasi berprestasi. Pengujian ini dilakukan untuk membuktikan ada atau tidaknya hubungan antara dua variabel tersebut, uji hipotesis dengan menggunakan analisis korelasi product moment dan teknik korelasi yang digunakan dalam penelitian ini adalah teknik korelasi sederhana yang ditampilkan dalam bentuk analisis regresi linier 
sederhana dengan menggunakan bantuan SPSS versi 16,0
Hasil dari uji korelasi dapat dilihat pada tabel berikut ini.

Tabel.6

Correlations

\begin{tabular}{llrr}
\hline & & ESQ & Motivasi berprestasi \\
\hline ESQ & Pearson Correlation & 1 & .174 \\
& Sig. (2-tailed) & & .082 \\
& $\mathrm{~N}$ & 101 & 101 \\
\hline Motivasibe & Pearson Correlation & .174 & 1 \\
rprestasi & Sig. (2-tailed) & .082 & \\
& $\mathrm{~N}$ & 101 & 101 \\
\hline
\end{tabular}

Hasil analisis pada Tabel.7 diatas menunjukkan bahwa nilai pearson correlation antara variabel nilai dasar ESQdengan motivasi berprestasi sebesar 0,174 dan nilai signifikansi 0,082 (nilai $p$ $>0,05$ ) yang berarti pada taraf signifikansi antara dua variabel menunjukkan adanya dua variabel tidak menunjukkan adanya hubungan antara nilai dasar ESQ dan Motivasi berprestasi $\left(\mathrm{H}_{0}\right.$ diterima $\mathrm{H}_{\mathrm{a}}$ ditolak).

Berdasarkan hasil perhitu-ngan koefisien korelasi dengan besar koefisien 0,174 diperoleh nilai $\mathrm{r}_{\text {hitung }}$ adalah 0,174 sementara $r_{\text {tabel }}$ 0.1956. Sugiyono (2010: 185), jika $r_{\text {hitung }}<$ (kecil) $r_{\text {tabel }}$ maka jika $\mathrm{r}_{\text {hitung }}<\mathrm{r}_{\text {tabel }}$ maka $\mathrm{H}_{0}$ diterima, $\mathrm{H}_{\mathrm{a}}$ ditolak. Sebaliknya, Jika $\mathrm{r}_{\text {hitung }}>\mathrm{r}_{\text {tabel }}$ maka $\mathrm{H}_{0}$ ditolak $\mathrm{H}_{\mathrm{a}}$ diterima .dari hasil di temukan bahwa $\mathrm{r}_{\text {hitung }}<$ (kecil) $\mathrm{r}_{\text {tabel }}(0.174<0.1956)$ dengan kesimpulan bahwatidak ada hubungan antara nilai dasar ESQ dan motivasi berprestasi pada mahasiswa Fakultas Ushuluddin".

Dasar pengambilan keputu-san dengan Uji t. Dalam menentukan $\mathrm{t}$ tabel dapat dicari pada $\alpha=5 \%: 2=2.5 \%$ atau 0.025 , dengan derajat kebebasan (df) n-2 atau $101-2=99$. Dengan pengujian dua sisi $\mathrm{t}$ tabel dapat dilihat pada nilai yang telah di tetapkan untuk signifikan 0.05 dan dengan derajat kebebasan 99 di dapatt tabel $=1.98$. Menurut Pratisto (2009:80), jika thitung besar dari tabel (thitung $>\mathrm{t}_{\text {tabel }}$ ), maka $\mathrm{H}_{0}$ ditolak.Dari hasil yang di dapat dalam penelitian ini bahwa thitung $<\mathrm{t}_{\text {tabel }}(1.75<198)$, maka $\mathrm{H}_{0}$ diterima, artinya $\mathrm{H}_{\mathrm{a}}$ di tolak dan $\mathrm{H}_{0}$ diterima. Maka kesimpulannya adalah tidak ada hubungan antara Nilai dasar ESQ dengan Motivasi Berprestasi.

Berdasarkan hasil analisis data menggunakan uji t-test yang menunjukkan bahwa tidak ada hubungan antara nilai dasar ESQ dengan motivasi berprestasi mahasiswi fakultas Ushuluddin IAIN Imam Bonjol Padang. Pada hasil data mengunakan uji t-test di perolah bahwa $t_{\text {hitung }}<t_{\text {tabel }}(1.75<198)$, maka $\mathrm{H}_{0}$ diterima, artinya $\mathrm{H}_{\mathrm{a}}$ di tolak dan $\mathrm{H}_{0}$ diterima. Maka kesimpulannya adalah tidak ada hubungan antara Nilai dasar ESQ dengan Motivasi Berprestasi.

Hipotesa penelitian yang diajukan sebagai landasan dalam melaksanakan penelitian ternyata tidak terbukti, karena tidak ada hubungan antaranilai dasar ESQ dengan Motivasi berprestasi.Artinya mahasiswa yang mengikuti Nilai dasar ESQ tidak mempengaruhi motivasi berprestasi dalam perkuliahan atau kesehariannya. 


\section{SIMPULAN}

Dari hasil penelitian Nilai dasar ESQ yang telah dilakukan bahwa mahasiswa Fakultas Ushuluddin IAIN Imam Bonjol Padang, angkatan 2013 atau semester tiga dengan 101 subjek yang diteliti, ditemukan bahwa sebanyak 8 orang atau $8 \%$ memiliki tingkat atau bentukNilai dasar ESQ tinggi (positif). Sebanyak 52 orang atau $51 \%$ memiliki tingkat atau bentuknilai dasar ESQ yang sedang. Sebanyak 41 orang atau 41 $\%$.Dari besarnya persentase nilai dasar ESQ pada tabel tersebut, menunjukkan bahwa mahasiswa Fakultas Ushuluddin IAIN Imam Bonjol Padang Padang lebih dominan memiliki tingkat Nilai dasar ESQyang sedang.

Dari hasil penelitian Motivasi berprestasi yang telah dilakukan bahwa mahasiswa Fakultas Ushuluddin IAIN Imam Bonjol Padang, angkatan 2013 atau semester tiga dengan 101 subjek yang diteliti, ditemukan bahwa sebanyak 23 orang atau $23 \%$ memiliki tingkat Motivasi Berprestasi yang tinggi. Sebanyak 23 orang atau $23 \%$ memiliki tingkat motivasi berprestasi sedang.

\section{DAFTAR RUJUKAN}

Abdullah, Mas Udik, 2005, Meledakkan IESQ Dengan Langkah Takwah \& Tawakal Jakarta; Zikrul Hakim
Sebanyak 55 orang atau $54 \%$ memiliki tingkat motivasi berprestasi rendah. Dari besarnya persentase Motivasi Berprestasi pada tabel tersebut, menunjukkan bahwa Mahasiswa fakultas Ushuluddin IAIN Imam Bonjol Padang lebih dominan memiliki tingkat Motivasi berprestasi yang rendah.

Berdasarkan hasil analisis data menggunakan uji t-test yang menunjukkan bahwa tidak ada hubungan antara nilai dasar ESQ dengan motivasi berprestasi mahasiswa fakultas Ushuluddin IAIN Imam Bonjol Padang. Pada hasil data mengunakan uji t-test di perolah bahwa $t_{\text {hitung }}<\mathrm{t}_{\text {tabel }}(1.75<198)$, maka $\mathrm{H}_{0}$ diterima, artinya $\mathrm{H}_{\mathrm{a}}$ di tolak dan $\mathrm{H}_{0}$ diterima. Maka kesimpulannya adalah tidak ada hubungan antara Nilai dasar ESQ dengan Motivasi Berprestasi.

Tidak terdapat pengaruh yang signifikan antara ESQ dengan Motivasi beprestasi mahasiswa fakultas Ushuluddin Smt 3 IAIN Imam Bonjol Padang.Karena pelatihan nilai dasar ESQ dengan motivasi berprestasi merupakan 2 hal yang tidak berhubungan. Maka nilai dasar ESQ merupakan sesuatu yang berdiri sendiri. Dan motivasi berprestasi juga suatu yang tidak dipengaruhi oleh pemberian pelatihan nilai dasar ESQ. Karena faktor motivasi berprestasi yang di miliki oleh mahasiswa tidak hanya terkait pada pelatihan nilai dasar ESQ saja, tetapi bisa dari berbagai macam faktor, seperti fasilitas, keadaan lingkungan, semangat dari teman dekat.

Agustian, Ary Ginanjar, 2001, ESQ

(Emotional Spiritual Guotent), Bandung 
(Emotional Spiritual Guotent), Bandung

Arikunto,Suharsimi.2006. Prosedur Penelitian: Suatu Pendekatan Praktik. Jakarta: PT. Rineka Cita

Aziz, Moch, Syahzuddin. 2010. Pengaruh Nilai Dasar ESQ (Emotional Spiritual Quotient) Terhadap Perilaku Kerja Karyawan Bandung Sport Group Kota Malang. Fakultas Psikologi UIN Maulana Malik Ibrahim Malang

Azwar, S. 2003. Metode Penelitian. Yogyakarta : Pustaka Pelajar.

Azwar, S. 2005. Tes Prestasi ; Fungsi dan pengembangan Pengukuran Prestasi Belajar; Yogyakarta; pustaka pelajar.

Azwar, S. 2005. Reliabilitas dan Validitas.Yogyakarta; Pustaka Pelajar

2005. Metode Penelitian. Pustaka Pelajar; Yogyakarta. 2000. Penyusunan Skala Psikologi. Yogyakarta;Pustaka Pelajar:

Chaplin, J P. 2009. Kamus Lengkap Psikologi. Jakarta : PT. Raja Grafindo Persada.

Hamzah, 2013. Teori Motivasi Belajar Dan Pengukurannya. Jakarta : Bumi Aksara

Martono, Nanang. 2010, Metode Penelitian Kuantitatif (Analisis Isi Dan Analisis Data Sukunder), Jakarta ; PT Raja Grafindo Persada

Najati, Utsman. 2004. Psikologi dalam Perspektif Hadis.Jakarta : PT.Pustaka Al Husna Baru.
2005. Psikologi dalam AlQuran. Jakarta : PT.Pustaka Al Husna Baru.

Nursyamsi, 2003. Psikologi Pendidikan. Baitul Hikmah Press Padang

Prasetyo, Bambang, dkk. 2008. Metode Penelitian Kuantitatif. Jakarta : PT Raja Grafindo.

Pratisto, Arif, 2009. Statistik Menjadi Mudah Dengan SPSS 17. Pt Elex Media Komputindo, Jakarta

Priyatno, Duwi. 2011. SPSS. Jakarta : PT Buku Seru.

Purwanto, Ngalim 2010. Psikologi Pendidikan, Bandung

Sam'ani. 2008. Penerapan Emotional Spiritual Quotient (ESQ) untuk meningkatkan kinerja karyawan. Jurnal.

Sobur, Alex 2010. Psikologi Umum, Bandung, Pustaka Setia

Sugiyono.2011. Metode Penelitian Kuantitatif Kualitatif dan $R \& D$.Bandung :Alfabeta.

Rola ,F. 2006. Konsep Diri Remaja Penghuni Panti Asuhan, Diperoleh 20 maret 2008 Dari http//www.glospot.ac.id. 2006. Konsep Diri dengan Motivasi Berprestasi pada Remaja. Diperoleh 20 maret 2008 Dari http//www.glospot.ac.id.

Widoyoko. P. E. 2012. Teknik Penyusunan Instrumen Penelitian. Yogyakarta : Pustaka Belaja

Yudhawati, Ratna, 2011, Teori-Teori Dasar Psikologi Pendidikan, Jakarta : PT. Prestasi Pustakaraya 